\title{
Sustainability of Deposit Insurance Corporation for the Customers and Insurance Companies in Indonesia Paradigm
}

\author{
THERESIA ANITA CHRISTIANI
}

Faculty of Law, UNIVERSITAS ATMA JAYA YOGYAKARTA, INDONESIA. E-mail: anita.christiani@uajy.ac.id

\begin{abstract}
Insurance companies are under the Financial Services Authority's regulation and supervision in Indonesia. The fact is that there are several companies that experience problems in carrying out their obligations to customers. This situation causes losses for customers and public trust in insurance companies. The legal problem raised is the ideal legal protection for customers and insurance companies to be sustainable? The results show that the ideal legal protection for customers and insurance companies is the availability of implicit and explicit legal protection forms. The Deposit Insurance Corporation is needed, which requires all insurance companies to become participants in the guarantee period. This research is a normative research.
\end{abstract}

Keywords: Company; Deposit; Explicit; Insurance

JEL Classification: K2, K23 


\section{Introduction}

This economic activity requires the existence of the law to provide legal protection to the community. Based on Law Number 21 of 2011 concerning the Financial Services Authority, the Financial Services Authority is assigned to implement Indonesia's financial institutions' regulation and supervision. An insurance company is one of the financial institutions under the Financial Services Authority's regulation and supervision. The results also show that insurance companies can reduce the cost of social protection. Facts in practice as current problem show that there are several legal issues related to insurance companies in Indonesia. The case of the Jiwasraya Insurance Company, Bumi Putera Insurance Company Finally, with the action of the Financial Services Authority to limit business activities in the Life Insurance sector of PT Asuransi Jiwa Kresna (OJK 2020). This problem impacts insurance companies' ability to carry out their obligations and public trust in insurance companies. Legal issues in financial institutions, both from an operational aspect or other factors, are risks in a company. This situation will affect public confidence in financial institutions and the Insurance Company. The legal problem raised is the ideal legal protection for customers and insurance companies to be sustainable?. This research aims to find the ideal legal protection for customers and insurance companies to be sustainable. The State must provide legal protection to the community. This research is urgent because this insurance company's existence can be maintained by providing implicit and explicit protection forms (not yet available) for customers. Protection for insurance customers will positively correlate with the sustainability of insurance companies' existence as financial institutions in Indonesia.

Public trust in the insurance company is an important point that must be maintained, as said by Christophe $C$ and Cristina N (Courbage and Nicolas 2020). There is research conducted previously by Nurbaya Sari (Nurbaya, Zainal, and Edwardos 2013), who specifically researched insurance interests. Atiyeh Sadat also carried out the research (Atiyeh 2013). A recent study was conducted by the International Bar Association (BAR) regarding the risk insured, which examines legal expenses insurance (Anna Mc Nee, n.d.). Research conducted by Sandro RC, Elizabeth P, and William FW shows a close relationship between regulation and insurance, also research on insurance related to transgender issues and discrimination. Research related to insurance development was also carried out (Elizabeth G. Doolin et al. 2020, Qureshi, Muhammad Imran, et al. 2020). Yoichiro F, Michiko O, Mahito, O., Yusuke O., examined the relationship between advertising and insurance optimization (Fujii et al. 2020). Research on reinsurance companies has also been conducted (Han, Liang, and Young 2020). Those research can show the novelty of this research to be carried out.

This article describes the concept of legal relations in economic activities and the concept of legal protection. This concept is used to think about the need for legal intervention in supporting the objectives of insurance companies' activities in Indonesia. Next, a section that discusses the Financial Services Authority from Implicit Legal Protection and Deposit Guarantee Institution in An Explicit Protection will be presented. This section is important to write as a basis for analysis in proposing ideal legal protection for insurance companies in Indonesia.

\section{Literature Review}

\subsection{Legal Relations in Economic Activities.}

Hart's view shows that the law must be the ruler's order and constitute formal rules complemented by sanctions' existence. Hart is a thinker categorized under legal positivism. Legal positivism is an understanding that prioritizes procedural, rigid, and strict things. However, Hart's moral values still appear that law exists as a product of cultural aspects that fulfill physical elements and human existential elements. The basis of Hart's view is that there is a specific prevalence; this prevalence is then generalized. If it is considered acceptable, the social organization takes the organization's rules is willing to survive. Legal positivism considers that legal norms are considered the competent authority establishes the law, the contents will be binding, and there will be sanctions. 
Likewise, Lon Fuller's opinion on the law. Wayne Morrison (Peter M. Marzuki 2015).says that Fuller defines law as an ethical method to create and ensure social relationships. The legal system is a complex rule designed to save humanity from an uncertain situation. It also brings entry into the net to a full artistic and creative activity. The guidance used to create a social life is morality that arises because of human aspirations and morality that arises out of obligation. The main point of the rule of law is a moral reflection. The law must be based on a morality that arises from obligations. Morality must be found in the existence of rationality.

Economic activities are human activities in fulfilling their daily needs using a limited number of satisfying tools to get maximum satisfaction. From the macro aspect, the State carrying out its economic activities in achieving the welfare of the community requires laws to regulate economic actors' behavior in carrying out financial actions. The law in question is positive. Regulation in economic activities is urgent, especially when the imbalance of a stagnant situation and an unstable political situation is in place(Nina 2018) . It is just like Eric said. A. Posner and E. Glen Weyl, who said that "Private property is inherently monopolistic and how we would all be better of if private ownership were converted into a public auction for public benefits."(Posner and Glen. E. Weyl. 2018). This opinion shows that the State intervenes in arrangements that will regulate a specific economic position to benefit the people at large. Furthermore, Eric A. Posner also stated that if there is a situation where regulations cannot be enforced, It will fail to resolve human rights violations (Posner. E.A 2014). In the field of Intellectual Property Right, as one of the areas that drive the economy at this time, as stated by Heather A. Haveman (Heather A.H 2020): "Economists, sociologists, and legal scholars agree that intellectual-property law is fundamental to markets.

In essence, it is said that life activities, especially economic activities, require legal intervention, which can serve as guidelines for economic actors to ensure that economic activities are always aimed at the interests of many people.

\subsection{The Concept of Legal Protection}

The insurance company is one of the financial institutions in Indonesia. Apart from insurance companies, other financial institutions such as banking institutions, capital markets, and the Non-Bank Financial Industry. Currently, there are 139 insurance companies (including BPJS and Compulsory Insurance Providers). In the Financial Services Authority Quarter 1 report, a decrease in premium income is seen from the insurance performance in aggregate compared to the previous quarter's income. A decrease in insurance premium income by $20.45 \%$ (YoY) to Rp 87.71 trillion. Life Insurance still dominated premium income composition with a share of $46.5 \%$, followed by General Insurance and Reinsurance at $31.4 \%$, and BPJS at $18.8 \%$. The decline was because, in 2019, there were several cases related to non-payment made by several insurance companies that were considered "big" so far. These companies include the Bumi Putera Insurance company and Jiwasraya Insurance Company.

The agreement which is the source of a legal relationship (Mertokusumo 2019). The legal relationship is meant as an engagement. An agreement can be sourced from an agreement or because of law. An agreement is a legal relationship between two people that has legal consequences. Legal protection is a guarantee of the implementation of rights and obligations. Likewise, in the insurance agreement, the policy as a form of insurance agreement must be read by the related parties. The insured must read the contents of the agreement because the agreement's contents will affect the implementation of the agreement. (Matthew S et al., 2020)

The types of legal protection can be divided into, Preventive Legal Protection and Repressive Legal Protection. Preventive legal protection is provided before a government decision takes the definitive form. Repressive legal protection is protection aimed at resolving disputes. Many disputes arise from the insurance agreement. (Lentz and Reeves 2017). There is an opinion that says there is a need for a lawyer to handle the issue of fulfilling this insurance company obligation (Jan Moerland. 2016) .Insurance companies originate from the agreements made (Feinman Jay M. 2018). Several previous studies related to the existence of the right to sue from customers in the event of a loss (Faridatul 
2019). There is also research on insurance related to transgender issues and discrimination .Research related to insurance development was also carried out (Elizabeth G. Doolin et al. 2020).

\section{Methodology/Materials}

This research is normative. Normative research is research conducted using data that focuses on secondary data. The research used is natural law research in the domain of normative juridical studies. This research uses a qualitative model. This research was conducted with literature research to obtain secondary data in the legal sector. After the data has been collected, both primary and secondary legal materials, the next step is to process and analyze it. Data in the form of primary and secondary legal materials and data obtained from informants are collected and systematized, then described and analyzed. The data acquired will be analyzed using qualitative analysis using legal theory and legal philosophy to answer the problem. Data analysis was performed using qualitative data analysis techniques and conceptual and regulatory approaches. Thinking process in concluding using deductive thinking processes.

\section{Results and Findings}

\subsection{Financial Services Authority in the Perspective of Implicit Legal Protection for Insurance Customers}

Implicit legal protection is legal protection provided by the State before a dispute occurs. The implicit form of legal protection is regulations and supervision to implement these arrangements by the authority given the duties and authorities. The Financial Services Authority is an institution based on Law No. 21 of 2011. The Financial Services Authority has the responsibility and authority to regulate and supervise financial service institutions in Indonesia, including insurance companies. The financial service institutions currently under the Financial Services Authority's regulation and supervision are the Capital Market and the Non-Bank Financial Industry. The non-bank financial industry includes insurance companies. Pension fund. Financing Institutions, Special Financial Services Institutions, and Microfinance Institutions.

Based on Article 4, the Financial Services Authority's objectives are. First, all financial services sector activities are carried out legally, transparent, and accountable. Second, to realize a financial system that grows sustainably and stably, and Third, to protect customers and society's interests. In achieving these objectives, the Financial Services Authority is given the task and authority to encourage legal formation objectives.

The duties of the Financial Services Authority are stated in article 6 of the Financial Services Authority Law. The Financial Services Authority's obligations are to carry out regulations and supervision of activities in the banking sector, the capital market, financial services activities in the insurance sector, funds pension, financial institutions, and other financial service institution activities. This provision indicates that an insurance company is an institution whose regulation and supervision are under the Financial Services Authority. In macro terms, it can be analyzed that the Financial Services Authority's establishment has consequences for the change in each financial institution's authority. Before the Financial Services Authority's existence, capital market supervision and regulation were under the Capital Market Supervisory Institution, banking institutions were under the regulation and supervision of Bank Indonesia, and insurance companies were under the Ministry of Finance regulation and supervision.

Based on the description above, it can be seen that the insurance company is one of the institutions whose regulation and supervision is under the Financial Services Authority. Financial institutions that are the domain of supervision and regulation of the Financial Services Authority are banking institutions, capital markets, and the Non-Bank Financial Industry in Indonesia. Regulation and supervision of the Financial Services Authority is an implicit form of protection to maintain public trust. It is a form of state interference in the economic field. It is a manifestation of the close relationship 
between law and economy. In the economic field, it is still relevant to say that the purpose of the law is to realize the value of certainty and the value of justice, and the value of the benefit to society, as stated by Radbrucht.

From differentiating forms of legal protection, the centralization of regulation and supervision under the Financial Services Authority manifests implicit legal protection. This legal protection has a form of protection that prevents a bad situation from occurring in the insurance company, which results in the insurance company having the potential to experience problems in carrying out obligations to insurance customers.

\subsection{Deposit Guarantee Institution in an Explicit Protection Perspective of Insurance Customers}

Indonesia has a Deposit Insurance Corporation based on Law Number 24 of 2014 concerning the Deposit Insurance Corporation. According to the Law, the Deposit Insurance Corporation has two functions: ensuring deposits of depositors and actively maintaining the banking system's stability. The law includes, among others, participation and the number of guaranteed deposits. Participation in the Deposit Insurance Corporation guarantee is mandatory for every bank institution carrying out Indonesia's activities. These banks include branch offices of overseas banks operating in Indonesia's territory, commercial banks, and rural banks that operate conventionally and in sharia. The amount of guaranteed deposit value is regulated in Government Regulation No. 66 of 2008 concerning the amount of guaranteed deposit value. Changes in the number of deposits guaranteed are intended to anticipate the global financial crisis's impact. Article 11 of the Law on the Deposit Insurance Corporation promulgated in 2004 guarantees a maximum deposit value of IDR 100,000,000 (one hundred million rupiahs). Based on this government regulation, the guaranteed amount is increased to a maximum of IDR 2,000,000,000. (two billion rupiahs). This provision does not apply to deposits from bank customers whose business license was revoked before this PP came into effect. Increase in the value of deposits guaranteed by the Deposit Insurance Corporation from IDR 100,000,000 (one hundred million rupiahs) to $2.000,000,000$ IDR (two billion rupiahs). The threat originates from the global financial crisis, which is feared to trigger the community's simultaneous withdrawals of funds. If this situation was not immediately addressed, preventive measures could lead to bank collapse triggered by the current global crisis threat. Based on the description above, it can be seen that the Deposit Insurance Corporation, based on its function, task, and authority, is an institution that embodies explicit protection for banking customers. The juridical facts stipulate that the Deposit Insurance Company is only for its membership obligations to banking institutions. It is implied that customers of financial institutions who will be compensated for payment failure are only bank customers.

\subsection{Proposed Concept of Ideal Legal Protection for Insurance Companies}

Conceptually, the deposit insurance company is an institution that will provide payment guarantees if the financial institution has problems with the implementation of the financial institution's payment obligations or failed to fulfill its obligations. This payment guarantee is necessary to maintain public trust in financial institutions. This public trust has positive relevance to macroeconomic stability.

In Indonesia, currently, insurance customers only receive implicit legal protection. This implicit legal protection was realized by transferring the regulatory and supervisory authority for insurance companies from the Ministry of Finance to the Financial Services Authority. The Financial Services Authority has the task of regulating and supervising insurance companies. The Authority of the Financial Services Authority in making regulations to impose sanctions if the insurance company does not carry out its obligations is an effort to maintain its health. The facts in practice show that this implicit protection is insufficient to maintain public trust in insurance companies. The existence of several cases and problems with insurance companies in Indonesia shows that the regulatory and supervisory factors of insurance companies under the Financial Services Authority are not sufficient when viewed from the concept of legal protection and e Insurance Company sustainability. This 
situation is because the health of an insurance company is affected by the implementation of supervision and regulation by the Financial Services Authority but is mainly influenced by each of these insurance companies' operational behavior. The last factor is not easy to control and interfere with the competent authority. Based on the facts that occur and the existing normative facts, a deposit insurance Corporation provides compensation or guarantees against the failure of payment of insurance companies to customers, which must be pursued. However, the juridical fact that there is explicit legal protection for customers of banking institutions can be the basis for thinking for an explicit protection mechanism for customers of insurance companies. The experience of the monetary crisis that led to the Deposit Insurance Corporation's birth and the Deposit Insurance Corporation's reliability in facing the global crisis that occurred in 2008 can serve as a conceptual illustration for the guarantee of public funds entrusted to insurance companies in Indonesia. Figure 1 can show ideal legal protection for customers and insurance companies in Indonesia.

Figure 1. Ideal legal protection for insurance customers and insurance companies in Indonesia

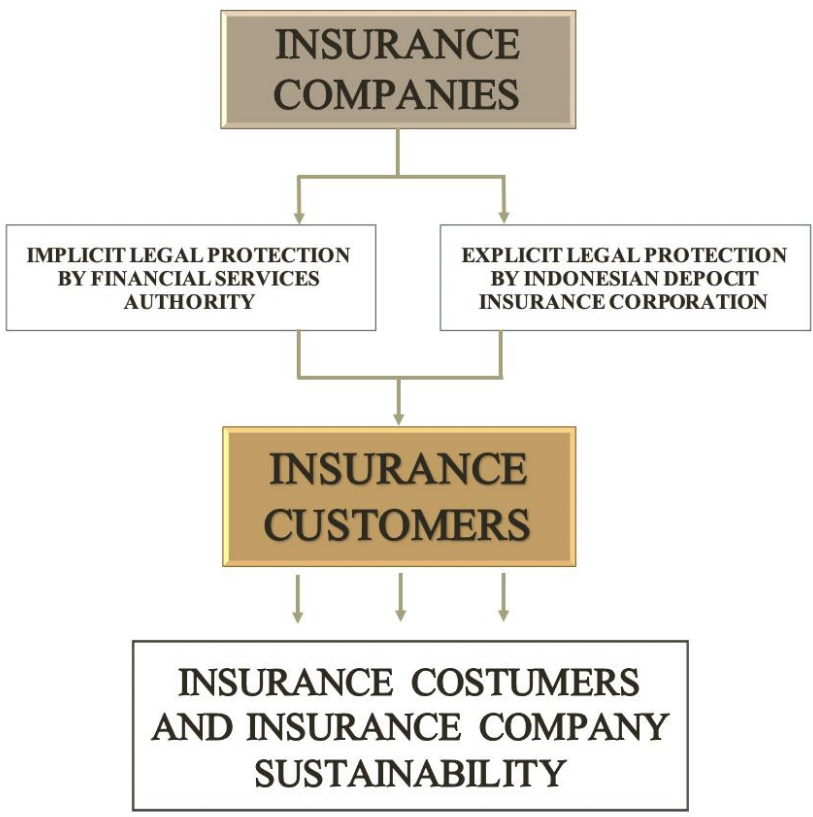

The suggestion to have a deposit insurance mechanism designated for insurance company customers is a customer protection mechanism that will explicitly demonstrate the State's will through the legislators so that legal norms in society can provide legal protection to the public.

As a country that adheres to a Civil Law System, which requires rigid procedures, formally, the Deposit Insurance Corporation's regulations with all its dynamics meet the formal and procedural requirements as law, as stated by Hans Kelsen Harts and Radbruch (David Howard and Sonna Wilson Stark 2018).

Substantively, the regulations issued above also show the will to provide a sense of justice and benefit to the community. Justice for society is because it is not only the customers of banking institutions that are equipped with explicit protection through deposit insurance companies, but customers of insurance companies should receive state intervention in realizing legal protection. This value of justice is following the opinion of Gustav Radbruch.

A law is considered valid if it meets these three values. The value of justice in law is related to philosophical aspects, which can be interpreted as the desired value. Gustaf Radbruch is an opinion that originates from the opinion of Immanuel Kant, who said that life has two areas, namely the realm of facts (das Sein) and the realm of it (das Sollen). Gustav Radbrucht considers culture to be a field that can be a link between the realm of facts and the supposed elements (FX Adjie Samekto 2015). Culture is considered an embodiment of value in the realm of facts, which can relate the domains of reality 
and the supposed retreat. According to Gustav Radbruch, culture is an element that can connect the aspects of facts and factors that should be because the culture is a manifestation of the elements of values that exist in the realm of facts in the form of human behavior and regulations. It becomes clear that culture is the link between the supposed elements and elements in the realm of facts. Laws or regulations have the values of society, including the value of justice. The law that is the embodiment of the value of justice, then in the implementation of the law itself, may not leave the value of justice. The value of justice must always be pursued into a spirit and manifested in real regulations. Is It is not that law is the embodiment of the value of justice in society, so it is only natural that law is formed to realize justice's value.

The explanation above explains that the existence of a Deposit Insurance Corporation, which has a function in guaranteeing customer deposits from insurance companies, is influenced by legal positivism understanding. The influence of legal positivism, which prioritizes formal or juridical aspects. It does not ignore the value of justice, which is the value that is the source of agreement from the community, which is then stated in a legal form following existing regulations. Experience in guaranteeing customer deposits with existing banking institutions will provide a good experience for the inclusion of Insurance Companies participation in Indonesia's Deposit Guarantee mechanism. The manifestation of explicit protection through the inclusion of the Insurance company's involvement in the Deposit Insurance Corporation is a form of the State's will in the framework of realizing the value of justice, the value of the benefit, and the value of legal certainty.

\section{Conclusion}

This research aims to find the ideal legal protection for customers and insurance companies to be sustainable. This research is urgent because this insurance company's existence can be maintained by providing implicit and explicit protection forms (not yet available) for customers. Protection. for insurance customers will positively correlate with the sustainability of insurance companies' existence as Indonesia's financial institutions. Based on the regulatory and conceptual approach used in this research, it can be concluded that conceptually legal protection can be divided into implicit legal protection and explicit protection. The two forms of legal protection are an ideal form of legal protection for the community. The insurance customers are not the party to be compensated if there is a payment failure, the Insurance Company's obligation. The Deposit Insurance Corporation in Indonesia provides guarantees only for deposits from customers of banking institutions. The protection of insurance customers in Indonesia only has an implicit form of legal protection through the Financial Services Authority's regulation and supervision. This situation will certainly not optimize the protection of insurance customers. The proposal for ideal legal protection for customers and insurance companies to be sustainable is the inclusion of insurance companies as deposit insurance participants as part of the manifestation of explicit legal protection for customers. This explicit customer protection mechanism will complement and strengthen insurance customer protection and implicit legal protection.

This research produces the concept of the ideal legal protection for customers and insurance companies to be sustainable. Still, it requires further research that is more focused on insurance implementation for customer insurance. This continued research is critical so that protection against insurance customers and insurance companies can be realized.

The implication of this study for insurance companies is that insurance companies are obliged to consistently implement regulations, as a form of implicit protection, both for insurance customers and for the sustainability of the insurance companies themselves. The implication of this research for the Financial Services Authority is that it focuses more on monitoring the implementation of regulations for insurance companies and their law enforcement. The government's research implication is that this ideal protection concept will be the basic concept for the formation of the guarantee mechanism of The Deposit Insurance Corporation for insurance companies in Indonesia. The implication of this 
research for the community is to strengthen understanding in choosing insurance institutions as a form of explicit legal protection.

\section{References}

1. Anna Mc Nee. n.d. "Legal Expenses Insurance and Access to Justice." 4.

2. Atiyeh, S.J., Alireza, H. 2013. "Review Insurance Contract ." International Journal of Development Research, 3 (12).

3. Courbage, Christophe, and Christina Nicolas. 2020. "Trust in Insurance: The Importance of Experiences." Journal of Risk and Insurance, September. https://doi.org/10.1111/jori.12324.

4. David Howard, and Sonna Wilson Stark. 2018. "HLA Hart"s Secondary Rules: What Do "officials' Really Think?,." International Journal of Law in Contexts, 14 (1).

5. Elizabeth G. Doolin, Julie F. Wall, Joseph R. Jeffery, and Victor F. Terrizzi. 2020. "Recent Developments in Health Insurance, Life Insurance, and Disability Insurance Law. 2020: Vol 55, No 2, Spring." Tort Trial and Insurance Practice Journal: 55 (2).

6. Faridatul. 2019. "Annuitant Legal Protection Associated with Fact No 40 of 2014 about the Insurance Business." Journal of Legal, Ethical and Regulatory Issues 22 (1).

7. Feinman Jay M. 2018. "Contract and Claim in Insurance Law,." Connecticut Insurance Law Journal 25 (1).

8. Fujii, Yoichiro, Michiko Ogaku, Mahito Okura, and Yusuke Osaki. 2020. "How Do Optimistic Individuals Affect Insurance Advertisements?" Asia-Pacific Journal of Risk and Insurance 14 (2). https://doi.org/10.1515/apjri-2019-0039.

9. FX Adjie Samekto. 2015. Pergeseran Pemikiran Hukum Dari Era Yunani Menuju Post Modernisasi. Jakarta: Konstitusi Press.

10.Han, Xia, Zhibin Liang, and Virginia R. Young. 2020. "Optimal Reinsurance to Minimize the Probability of Drawdown under the Mean-Variance Premium Principle." Scandinavian Actuarial Journal 2020 (10). https://doi.org/10.1080/03461238.2020.1788136.

11.Heather A.H. 2020. "Cultural Spillovers: Copyright, Conceptions of Authors, and Commercial Practices." Law \& Society Review 52 (1): 7-undefined.

12.Jan Moerland. 2016. "The Importance of In-House Legal Services in Legal Protection Insurance." Wiadomości Ubezpieczeniowe.

13.Lentz, Daniel G., and Robert M. Reeves. 2017. "Business Interruption Insurance Claims." In Litigation Services Handbook. Hoboken, NJ, USA: John Wiley \& Sons, Inc. https://doi.org/10.1002/9781119363194.ch12.

14. Mertokusumo, S. 2019. Mengenal Hukum. Yogyakarta: Penerbit Cahaya ATma .

15.Nina, B. 2018. "Beyond The Shareholder Coprporation,: Alternatives Business Fprms and Contestation Of Markets." Journal Of Law and Society 14 (1).

16.Nurbaya, Sene., A., Zainal, and B.S., Edwardos. 2013. "Insurance Customer Protection Is an Evening (Fortuitous Event )." International Journal of Multicultural and Multireligious Understanding 7 (5): undefined.

17.OJK. 2020. "Otoritas Jasa Keuangan Batasi Kegiatan Usaha PT Asuransi Jiwa Kresna-Di-BidangAsuransi-Jiwa." Www.Ojk.Go.Id. 2020.

18.Peter M. Marzuki. 2015. Pengantar Ilmu Hukum. Jakarta: Kencana.

19.Posner. E.A. 2014. The Twilight of Human Right Law. United Kingdom: Oxford University.

20.Posner, E, A, and Glen. E. Weyl. 2018. Radical Markets, Uprooting Capitalism and Democracy for A Just Society. New Jersey: Princetoon University Press.

21.Qureshi, Muhammad Imran, et al. "Classifications of sustainable manufacturing practices in ASEAN region: A systematic review and bibliometric analysis of the past decade of research." Sustainability 12.21 (2020): 8950. 